\title{
Bożena Aksamit, Piotr Głuchowski, Uzurpator. Podwójne życie prałata Jankowskiego
}

Wydawnictwo Agora, Warszawa 2019, 709 ss.

https://doi.org/10.19195/1643-0328.30.12

Ksiądz prałat Henryk Jankowski to postać doskonale znana w polskiej przestrzeni publicznej, która aż do 2019 roku nie doczekała się jednak próby naukowej weryfikacji. Znany jest życiorys księdza, wpierw bohatera nie tylko gdańskiej, ale ogólnokrajowej „Solidarności”, będącego organizatorem wizyt światowych przywódców, takich jak Margaret Thatcher czy Edward Kennedy, pomysłodawcy majestatycznego bursztynowego ołtarza w gdańskim kościele pod wezwaniem świętej Brygidy; zmarł w samotności, biedzie i niesławie, otoczony ledwie garstką przyjaciół, a na jego pogrzebie nie stawił się nawet wieloletni przyjaciel kapłana — Lech Wałęsa. W konsekwencji Jankowskiego oskarżono o czyny niegodne nie tylko kapłana katolickiego, ale każdego człowieka, co postanowili opisać dziennikarze współpracujący z „Gazetą Wyborczą” - Bożena Aksamit i Piotr Głuchowski. To pierwsza próba naukowego wyjaśnienia fenomenu człowieka, który z jednej strony do dziś jest kochany i uwielbiany przez dużą grupę ludzi, zwłaszcza wierzących, a z drugiej - dla niektórych jest uosobieniem zła. Tytuł tej publikacji: Uzurpator. Podwójne życie prałata Jankowskiego zdaje się więc niezwykle trafny do opisu życia jednego z najbardziej znanych kapłanów Wybrzeża.

Kryzys wizerunkowy, który spotkał księdza Henryka Jankowskiego po jego śmierci, zwłaszcza w roku 2018, zaraz po ukazaniu się artykułu współautorki publikacji - Bożeny Aksamit — w dodatku do „Gazety Wyborczej” — „Duży Format”, zatytułowanego Sekret Świętej Brygidy. Dlaczego Kościót przez lata pozwalał księdzu Jankowskiemu wykorzystywać dzieci?, niejako prowokował do podjęcia próby stworzenia pierwszego rzetelnego życiorysu księdza prałata, uwzględniając blaski i cienie jego działań. Publikacja Uzurpator..., zbudowana zgodnie z naukowym kanonem, z przypisami oraz bibliografią, jest de facto pierwszą naukową pracą poświęconą księdzu Henrykowi Jankowskiemu.

Celem publikacji, wskazanym przez drugiego z autorów - Piotra Głuchowskiego - już po śmierci Bożeny Aksamit, we wstępie zatytułowanym Pamięci Bożeny, jest przedstawienie wszystkich faktów dotyczących życiorysu oraz działalności księdza Jankowskiego oraz zbadanie, dlaczego i w jaki sposób hierarchia kościelna oraz decydenci polityczni podejmowali się obrony dobrego imienia kapłana oraz obstawali przy nieujawnianiu jego homoseksualnych oraz pedofilskich skłonności. Autorzy zapowiadają 
także próbę przeanalizowania przyczyn takiej działalności oraz jej skutków dla ofiar czy wspólnoty kościelnej. Niestety cele te zostały osiągnięte tylko częściowo, co wykażę $\mathrm{w}$ dalszej analizie walorów merytorycznych tej pracy.

Publikacja, której dotyczy ta recenzja, została podzielona na sześć części, z których każda zawiera w sobie od trzech do dwunastu rozdziałów.

Część pierwsza, zatytułowana Brudnopis, to swoista synteza wszelkich oskarżeń formułowanych wobec księdza Jankowskiego, dokonana przez autorów. Przedtem czytelnik dowiaduje się jednak o dzieciństwie księdza oraz rzeczywistości II wojny światowej, w której przyszło mu funkcjonować. Mimo historycznych nieścisłości, o których szerzej wspomnę w krytycznej części recenzji, autorzy trafnie ukazują dzieciństwo Henryka Jankowskiego w czasie wojennej pożogi, wraz z utratą przez chłopca ojca, wcielonego niemal siłą do Wehrmachtu. W tej części cennym elementem pracy są relacje żyjących jeszcze świadków tamtych wydarzeń oraz wyjaśnienie, że Armia Czerwona przybywająca na tereny nadmorskie, na których po upadku Wolnego Miasta Gdańsk żyło jeszcze wiele rodzin niemieckich bądź mieszanych, traktowała je mniej łagodnie w swych grabieżach i napaściach seksualnych niż mieszkańców innych części kraju. Po tym stricte biograficznym wstępie następuje wskazana na początku tego akapitu prezentacja zarzutów popartych relacjami domniemanych ofiar oraz świadków: o molestowanie dzieci w czasie wikariatu w Gdańsku w latach siedemdziesiątych XX wieku, o kontakty seksualne z klerykami, już jako proboszcz, oraz o współpracę ze Służbą Bezpieczeństwa PRL. Są one należycie udokumentowane, choć trudno nie odnieść wrażenia, że zaprezentowane dość tendencyjnie.

Druga część monografii zawiera przedstawienie skomplikowanych i często sprzecznych z sobą opisów ważnych wydarzeń z życia księdza Jankowskiego, prezentowanych przez naocznych świadków działania bohatera tej pracy. Znajdują się tutaj zarówno cytaty z zeznań znanych już z innych publikacji na temat prałata, jak i wypowiedzi uzyskane przez autorów książki, której dotyczy ta recenzja. Niestety mam wrażenie, że fakty zaprezentowano w sposób chaotyczny. Nie ma tutaj mowy o relacji chronologicznej, gdyż wydarzenia kolejnych rozdziałów nie następują po sobie. Trudno również dopatrzeć się analizy i prezentacji problemowej - zagadnienia są rozrzucone daleko od siebie i tylko luźno powiązane. Dotyczą one takich kwestii, jak postać Petera Rainy — biografa i przyjaciela Henryka Jankowskiego, dalszych oskarżeń o współpracę z SB, domniemanego zamachu na Jankowskiego jeszcze w czasie jego działalności w NSZZ „Solidarność”, kolejnych kontaktów seksualnych z nieletnimi chłopcami czy wygłaszanych przez kapłana antysemickich treści w czasie sprawowania funkcji proboszcza.

Podobnie rzecz się ma w trzeciej części pracy. Choć jest ona najobszerniejsza, to również w niej nie sposób doszukać się ciągu przyczynowo-skutkowego. Autorzy przedstawiają tutaj dalsze oskarżenia o wykorzystywanie seksualne nieletnich, potwierdzone relacjami świadków oraz prokuratorskimi dokumentami. Dużą wartością tego fragmentu pracy jest rozdział o antysemickim podłożu wypowiedzi kapłana, a ta jakże naganna postawa została znakomicie udokumentowana i potwierdzona zapisem licznych homilii i zdjęciami z wystroju kościoła, zwłaszcza stricte politycznych i antysemickich Grobów 
Pańskich. W tej części przedstawiono także argumenty obrońców księdza Jankowskiego oraz przykłady jego niesmacznych wypowiedzi, zwłaszcza w stosunku do kobiet.

Czwarta część to kontynuacja wątków zarysowanych w końcu „działu” trzeciego. W tym fragmencie praca zyskuje pewną spójność. Na treść ukazanych w niej rozdziałów składają się udokumentowane kontrowersyjne wypowiedzi duchownego na przestrzeni lat wraz ze stosownym komentarzem nie tylko samych autorów, ale też świadków tychże wypowiedzi. Autorzy w dobry sposób przedstawili pewną sprzeczność w naturze księdza, który jednego dnia jadł elegancką kolację na plebanii z prof. Zbigniewem Brzezińskim i przywódcami NSZZ „Solidarność”, by drugiego rzucać niewybredne i skrajnie seksistowskie komentarze w stosunku do przypadkowo napotkanej kobiety.

Części piąta i szósta odnoszą się do wydarzeń już po śmierci księdza Jankowskiego. W części piątej kolejne rozdziały ukazują uroczystość jego pogrzebu wraz z fragmentami homilii, czy raczej laudacji na cześć zmarłego, dokonanej przez arcybiskupa Metropolitę Gdańskiego - Sławoja Leszka Głodzia. Również tutaj znajdują się argumenty obrońców dobrego imienia prałata, w tym szeroki opis wydarzeń rozgrywających się w Gdańsku podczas „walki o pomnik” księdza Jankowskiego. Ostatnia część to natomiast opis wydarzeń po ukazaniu się artykułu Bożeny Aksamit w „Dużym Formacie”, dzięki któremu szeroka opinia publiczna dowiedziała się o wątpliwych moralnie praktykach księdza z Gdańska. Niezwykle cenna w tym rozdziale jest wypowiedź prof. Zbigniewa Lwa-Starowicza - seksuologa badającego niegdyś osobowość księdza Jankowskiego; ten doceniany ekspert stwierdził ponad wszelką wątpliwość, że kapłan był homoseksualistą i mógł dokonywać praktyk, o które jest oskarżany.

Niewątpliwie mamy tutaj do czynienia z monografią. Jest to bowiem pierwsze całościowe, niezwykle kompleksowe i szerokie ujęcie biografii oraz licznych wydarzeń związanych z życiem księdza Henryka Jankowskiego. Zastanawiająca jest jednak struktura pracy. Choć tworzy ona dość logiczną i spójną całość, to czytelnik musi przyzwyczaić się do pewnych retrospekcyjnych „wrzutek” w kolejnych rozdziałach. Czytając tę monografię można odnieść wrażenie, jakby czytało się kilka książek naraz. Po zakończeniu lektury pozostaje jednak wrażenie spełnienia, chociaż samo czytanie jest chaotyczne i wymaga łączenia szeregu powierzchownie niezwiązanych z sobą wątków. Znając jednak biografię duchownego, można przyznać rację autorom co do wyboru takiej konstrukcji tej pracy, która swoją chaotycznością oddaje niejako życie głównego bohatera. Tą wyjątkową barwność życiorysu oraz chaos wewnętrzny księdza Jankowskiego w pełni oddano w pierwszej pełnej biografii kapelana „Solidarności”.

Nie da się ukryć, że praca ta ma wiele atutów. Wśród nich należy wyróżnić:

— znakomicie zgromadzony materiał źródłowy - autorzy cytują niemal każdą, nawet najbardziej skrajną publikację na temat księdza Jankowskiego, która opuściła oficyny wydawnicze, także te niszowe, starając się ukazać logikę, nawet najbardziej toporną i niemerytoryczną, zarówno obrońców, jak i oskarżycieli kapłana;

- wykorzystanie wywiadów pogłębionych z ofiarami, ekspertami, przyjaciółmi i współpracownikami księdza oraz naocznymi świadkami wydarzeń, które są opisywane w monografii, by potwierdzić oraz uzmysłowić czytelnikowi kluczowe informacje i fakty; 
- właściwie dobrany zespół autorów - są to osoby od lat zajmujące się związkiem państwa polskiego oraz Kościoła katolickiego, jak również badające kwestie personalne - biografowie księdza Henryka Jankowskiego, a zwłaszcza osoby, które jako pierwsze zebrały nowe informacje o możliwości popełniania przestępstw na nieletnich przez bohatera tej pracy.

Niewątpliwie czytelnik znajdzie w tej monografii wiele ciekawostek i mniej znanych faktów z życia księdza Jankowskiego, a także pozna jego pełną biografię oraz nowe fakty, często odkrywane po latach, zwłaszcza o „ciemniejszej” stronie tej postaci. Nie zmienia to jednak faktu, że recenzent zmuszony jest wykazać liczne zafałszowania i nieścisłości, które można znaleźć w tej publikacji.

Pierwsza z nich dotyczy zaprezentowanego wcześniej podziału treści. Mimo zrozumienia zamysłu autorów, by stworzyć pracę wielowątkową, nieco zbliżoną swoją chaotycznością do życiorysu jej głównego bohatera, to jednak zaznajomienie się z treścią tej monografii może i stwarza trudności. Warto tutaj wskazać na przykład oskarżeń o seksualne wykorzystywanie dzieci. Autorzy, chroniąc dane ofiar kapłana, podają tylko ich imiona, a ponieważ każda niemal część publikacji zawiera oskarżenia wysuwane wobec księdza w różnych latach, pojawia się kłopot w należytym zrozumieniu przez odbiorcę, od kogo pochodzi dana wypowiedź, same imiona mogą mu się - najzwyczajniej rzecz ujmując - mylić.

Druga uwaga dotyczy zafałszowania pewnych faktów, zwłaszcza dość kluczowych wydarzeń historycznych. Doskonałą egzemplifikacją takiego zjawiska jest odniesienie do słów samego księdza, twierdzącego - jak się później okazuje: wbrew faktom historycznym — że jego ojciec od pierwszych dni września 1939 roku przebywał w niemieckim nazistowskim obozie koncentracyjnym w Stutthoff. Konkretnie, rzecz rozbija się o datę 6 września. Autorzy publikacji twierdzą, pisząc o tym zakłamaniu w wypowiedzi księdza, że jego ojciec nie był osadzony w obozie w Stutthoff (czyli Sztutowie), a w Nowym Porcie: „Antoni Jankowski siedział tam, a nie w Stutthoffie, bo tego obozu jeszcze wówczas nie zbudowano" (s. 18). Wbrew badaczom należy jednak stwierdzić, że Antoni Jankowski mógł przebywać w Stutthoff, gdyż obóz funkcjonował od 2 września 1939 roku, a co za tym idzie - zapis „tego obozu jeszcze wówczas nie zbudowano” jest kłamstwem.

Trzecie spostrzeżenie również dotyczy rozdziałów biograficznych. Niestety w wielu fragmentach autorzy przepisują całe strony książek Petera Rainy z lat wcześniejszych oraz biografii prałata Jankowskiego, napisanej w 2014 roku przez Jerzego Danilewicza, zatytułowanej Bursztynowy prałat. Choć są to elementy zacytowane prawidłowo, w obliczu dużej i pełnej monografii przytaczanie tak obszernych fragmentów innych dzieł stanowi pewien problem.

Ostatnia uwaga tyczy się większości treści i zdaje się odnosić do problemu największego kalibru. Czytając tę publikację, trudno bowiem nie odnieść wrażenia o stronniczości autorów. Są to dziennikarze „Gazety Wyborczej”, z którą jeszcze za życia często, nawet bardzo niewybrednie, polemizował ksiądz Jankowski. Książka ma więc mocne zabarwienie, na mocy którego daje się odczuć poglądy autorów na temat działalności postaci, którą opisują, jak również ich dość wyraźne poglądy antyklerykalne. To publikacja, 
w której Henryk Jankowski jest oceniany jednoznacznie negatywnie, podobnie jak jego obrońcy, natomiast relacje oskarżających go domniemanych ofiar są przyjmowane za prawdziwe bez mrugnięcia okiem, mimo - co warto zaznaczyć — braku prawomocnego wyroku w tej sprawie zarówno sądu świeckiego, jak i Stolicy Apostolskiej. Autorzy tej pracy nie wyzbywają się publicystycznego podejścia do tematu, co w połączeniu $\mathrm{z}$ ich wypowiedziami medialnymi podaje $\mathrm{w}$ wątpliwość walory naukowe publikacji.

Podsumowując, pracę Bożeny Aksamit i Piotra Głuchowskiego należy ocenić dość krytycznie. Choć autorzy zebrali rzetelną i kolektywną wiedzę na temat działalności i życia księdza Jankowskiego, to nie ustrzegli się zakłamań i zafałszowań historii. Niestety wiele wydarzeń pozostaje w sferze domysłów, a w licznych innych kwestiach, w tym tej zasadniczej - oskarżeń o pedofilię, musimy opierać się na opowieściach i relacjach osób znanych wyłącznie z imienia lub takich, których relacje nie znajdują żadnego twardego naukowego bądź prokuratorskiego potwierdzenia. W publikacji daje się wyraźnie dostrzec poglądy autorów, a ich życiorysy oraz dotychczasowe publikacje o zabarwieniu krytycznym wobec hierarchii kościelnej nakazują zachowywać pewien dystans w odbiorze treści. Nakładając jednak tę światopoglądową kalkę na obraz całej pracy, czytelnik może doszukać się w niej bardzo wartościowych i spójnych treści, dzięki którym dobrze pozna kompletną biografię księdza Henryka Jankowskiego. Publikacja ta ma niewątpliwie dużą wartość, choć zdecydowanie bardziej znajduje się w gatunku publicystyki niż prac naukowych. 